\title{
PEMANFAATAN INTERNET BANKING DAN AUTOMATIC TELLER MACHINE TERKAIT PENINGKATAN USAHA OLEH PELAKU UMKM PASAR INDUK WONOMULYO
}

\author{
Nurul Fitri ${ }^{1)}$ dan Nur Qamariah ${ }^{2)}$ \\ ${ }^{1,2}$ Fakultas Ekonomi, Universitas Sulawesi Barat \\ ${ }^{1,2}$ Jl. Prof Baharuddin Lopa, S. Talumung Majene Sulawesi Barat, 91412 \\ E-mail : nurulfitri@unsulbar.ac.id ${ }^{1)}$,nurqamariahsutji@gmail.com²)
}

\begin{abstract}
ABSTRAK
Penelitian ini bertujuan untuk mengetahui bagaimana persepsi pelaku UMKM Pasar Induk Wonomulyo terhadap penggunaan internet banking dan automatic teller machine terkait peningkatan usaha yang dijalankan, serta peningkatan pendapatan karena adanya kemudahan yang diberikan oleh pihak perbankan dalam bentuk fasilitas yang didukung dengan teknologi di Kecamatan Wonomulyo Kabupaten Polewali Mandar Sulawesi Barat. Metode yang digunakan dalam penelitian ini adalah kualitatif. Penelitian dilakukan selama 9 bulan (Maret-Novenber 2019) di Kecamatan Wonomulyo, yang dikhususkan pada Pasar Induk Wonomulyo sebagai lokasi penelitian. Penelitian menggunakan 52 responden yang terdapat di Pasar Induk Wonomulyio. Penelitian ini menemukan bahwa internet banking dan automatic teller machine (ATM) tidak memiliki pengaruh signifikan terhadap peningkatan usaha pelaku UMKM di Pasar Induk Wonomulyo. Kondisi ini terjadi karena sebagian besar dari pelaku UMKM yang menjadi responden masih melakukan transaksi jual beli secara tradisional. Penelitian ini juga membuktikan bahwa pelaku UMKM di Pasar Induk Wonomulyo kurang tersentuh revolusi industri 4.0, dimana pada revolusi industri 4.0 memicu adanya pemanfaatan smartphone dalam memudahkan dan meningkatkan hasil dari kegiatan/pekerjaan kita sehari-hari.
\end{abstract}

Kata Kunci: Umkm, Perbankan, Internet Banking, Atm, Peningkatan Usaha.

\section{PENDAHULUAN}

Tumbuh dan berkembang secara sistematis pada perekonomian masyarakat juga didukung oleh adanya pengembangan industri yang saat ini kita kenal dengan revolusi industri 4.0. Pemanfaatan teknologi dalam meningkatkan kualitas hidup, kemudahan dalam komunikasi yang didukung oleh smartphone dan masih banyak lainnya. Jika dikaitkan dalam dunia usaha maka perkembangan pemanfaatan teknologi mampu meningkatkan pendapatan yang ingin dicapai oleh pelaku bisnis, pelaku UMKM.

Pelaku UMKM yang berada di kecamatan wonomulyo mengembangkan usaha dengan adanya bantuan perbankan dalam bentuk pinjaman, yang kemudian digunakan sebagai modal tambahan dalam meningkatkan kegiatan usaha demi mencapai pendapatan yang diharapkan. Tumbuh dan berkembangnya perekonomian di wonomulyo memerlukan periode yang cukup panjang, dari ekonomi tradisional menuju ekonomi modern seperti saat ini.

Hal menarik untuk diamati adalah karena perkembangan ekonomi di wilayah ini berjalan seiring dengan perkembangan teknologi yang dapat dikatakan sangat pesat. Hal ini ditandai dengan adanya kestabilan hubungan atau interaksi yang saling mendukung antara kondisi pasar saat ini (terutama kebutuhan konsumen), kreatif dan inovatif dari pelaku pasar, perkembangan teknologi, perbankan, peningkatan produksi dan perdagangan antar wilayah sehingga tercipta peningkatan pendapatan masyarakat.

Dunia perbankan dikenal dengan pelayanan yang memberi kenyamanan pada nasabah. Kenyamanan merupakan variabel utama dalam menggunakan internet banking (Robert, 2013). Kenyamanan dalam internet banking adalah memudahkan nasabah untuk melakukan transaksi perbankan kapanpun dan dimanapun, menjadikan pengguna merasakan kenyamanan dalam bertransaksi.

Penelitian sebelumnya yang dilakukan Diana (2017) menunjukkan bahwa secara simultan maupun secara parsial kualitas ATM berpengaruh positif dan signifikan terhadap kepuasan nasabah. Hal ini menunjukkan peningkatan kualitas ATM secara langsung meningkatkan kepuasan nasabah. Demikian pula sebaliknya, penurunan kualitas ATM secara langsung menurunkan kepuasan nasabah perbankan. Berdasarkan penelitian di atas menunjukkan penggunaan ATM dapat memberikan dampak positif pada pelaku UMKM, faktor kualitas teknologi elektronik efektif mampu memicu peningkatan usaha karena adanya kemudahan transaksi. Oleh karena itu, berdasarkan uraian di atas, peneliti tertarik melakukan penelitian di Pasar Induk Wonomulyo yang menjadi salah satu tempat atau lokasi yang disebut sebagai pusat perdagangan di Sulawesi Barat. Penelitian dengan judul "Pemanfaatan Internet Banking dan 
Automatic Teller Machine terkait Peningkatan Usaha oleh Pelaku UMKM Pasar Induk Wonomulyo".

\section{RUANG LINGKUP}

1. Cakupan permasalahan.

1) Persepsi pelaku UMKM atas pemanfaatan internet banking dalam meningkatkan usaha.

2) Persepsi pelaku UMKM atas pemanfaatan automatic teller machine dalam meningkatkan usaha.

2. Batasan-batasan penelitian

Penelitian ini dibatasi dengan menilai manfaat internet banking dan ATM dari persepsi pelaku UMKM

3. Rencana hasil yang didapatkan.

Memberikan penjelasan kepada pelaku UMKM di pasar induk Wonomulyo bahwa dengan memanfaatkan fasilitas perbankan, secara spesifik pada internet banking dan ATM dapat meningkatkan usaha mereka. Serta, pemanfaatan smartphone secara maksimalkan dapat membantu dalam peningkatan penjualan pelaku UMKM sehingga revolusi industri 4.0 memberikan dampak positif dalam meningkatkan perekonomian suatu wilayah.

\section{BAHAN DAN METODE}

Bahan dalam penelitian ini terbagi menjadi dua pokok bahasan utama yaitu UMKM dan bank. UMKM menjelaskan tentang pengelompokan jenis usaha dan penjelasan singkat kegiatan usaha. Bank menjelaskan fasilitas yang diberikan perbankan dalam memudahkan nasabah dalam bertransaksi, terutama terkait variabel penelitian yaitu Internet Banking dan Automatic Teller Machine (ATM). Sedangkan pada metode penelitian memaparkan tahapan-tahapan penelitian.

\subsection{UMKM}

Berdasarkan Undang-undang nomor 20 tahun 2008, UMKM dibagi dalam tiga jenis usaha yaitu usaha mikro, kecil dan menengah, baik dalam bentuk perorangan maupun badan usaha. Usaha mikro hasil penjualan dibawah Rp.100.000.000, usaha kecil memiliki omzet dibawah Rp. 200.000.000 dengan besaran hasil penjualan berada pada kisaran Rp.100.000.000 hingga Rp.1.000.000.000, dan usaha menengah memiliki omzet diatas Rp. 200.000.000 dengan besaran hasil penjualan lebih dari Rp.1.000.000.000. Besaran omzet yang berbeda pada ketiga bentuk usaha ini akan sangat mempengaruhi tingkat pemasaran masing-masing.

Dasar pemikiran pemasaran sebagaimana yang dikemukakan Kotler (2010), dimulai dari kebutuhan dan keinginan manusia. Pemasaran yang lebih maju berorientasi pada strategi pasar, kualitas layanan, kepercayaan, nilai tambah, pengambilan keputusan, kepuasan dan loyalitas serta lainnya. Beberapa permasalahan yang sering dihadapi UMKM, khususnya industri kecil adalah pemasaran.
Semua keberhasilan yang telah dicapai oleh UMKM memiliki titik kelemahan yang harus segera diselesaikan meliputi kurangnya permodalan baik jumlah maupun sumbernya, kurangnya kemampuan manajerial dan minimnya keterampilan pengoperasi dalam mengorganisir dan terbatasnya pemasaran merupakan hal yang mendasar selalu dihadapi oleh semua UMKM dalam merintis sebuah usaha bisnis untuk dapat berkembang (Suci, 2017).

Kotler (2010) Perilaku konsumen adalah studi tentang bagaimana individu, kelompok, dan organisasi memilih, membeli, menggunakan, dan bagaimana barang, jasa, ide, atau pengalaman untuk memuaskan kebutuhan dan keinginan mereka. Studi perilaku konsumen terpusat pada cara individu mengambil keputusan untuk memanfaatkan sumber daya mereka yang tersedia (waktu, uang, usaha, fasilitas) guna membeli barang-barang yang berhubungan dengan konsumsi. Hal ini mencakup apa yang mereka beli, mengapa mereka membeli, kapan mereka membeli, di mana mereka membeli, seberapa sering mereka membeli, dan seberapa sering mereka menggunakannya. Perilaku pembelian konsumen dipengaruhi oleh faktor budaya, sosial, dan pribadi,dan Psikologis (Kotler, 2010).

\subsection{Bank}

Menurut Kasmir (2014) bank adalah badan usaha yang menghimpun dana dari masyarakat dalam bentuk simpanan dan menyalurkannya kepada masyarakat dalam bentuk kredit dan atau bentuk-bentuk lainnya dalam rangka meningkatkan taraf hidup masyarakat, jadi bukan hanya mencari keuntungan. Pengertian Lembaga Keuangan menurut UU No. 14/1967 Pasal 1 tentang Pokok-Pokok Perbankan mendefinisikan bahwa: Lembaga keuangan merupakan semua badan yang melalui kegiatan-kegiatannya di bidang keuangan, menarik uang dari dan menyalurkannya ke dalam masyarakat.

Pada berbagai bank yang ada telah menyediakan fasilitas berupa electronic banking untuk memudahkan kegiatan bertransaksi nasabah. Electronic Banking ( $E$ Banking) adalah suatu bentuk layanan yang memungkinkan nasabah, untuk mengakses rekening, melakukan transaksi, atau mendapatkan informasi produk bank melalui jaringan pribadi/publik (Laptop, telepon dll). Secara umum layanan perbankan yang menggunakan electronic adalah: Automatic Teller Machine (ATM), Kartu Debit, Kartu Kredit, Internet Banking, Short Message Service (SMS) Banking, Call Banking, Phone Banking.

Kebutuhan akan layanan yang optimal ini tak bisa dihindari karena tuntutan nasabah semakin tinggi. Kini misalnya, nasabah lebih memilih bertransaksi melalui delivery channel alternatif seperti Automated Teller Machine (ATM), internet, telepon atau pesan singkat (Short Message Service - SMS), bukan antri di bank. Nasabah dapat melihat saldo tabungan atau gironya, atau bertransaksi melalui ATM, internet dan telepon seluler, 
sambil berlibur di belahan dunia yang lain (Andriyani, 2014).

\subsubsection{Internet Banking}

$\begin{array}{cclc}\text { Menurut } & \text { Robert } & \text { (2013) internet banking } \\ \text { menyediakan } & \text { tingkat kenyamanan yang lebih, }\end{array}$
memudahkan nasabah untuk melakukan transaksi perbankan kapanpun dan dimanapun. Jika dibandingkan dengan transaksi perbankan tanpa menggunakan internet banking misalnya dengan transaksi interpersonal, internet banking memberikan lebih banyak keuntungan dan kemudahan. Seperti misalnya, jika ingin membayar tagihan atau mentransfer uang, apabila melalui kantor cabang, maka nasabah harus mengantri lama untuk melakukan transaksi tersebut. Hal ini, sesuai dengan hasil penelitian Harlan (2014) terdapat pengaruh positif signifikan kepercayaan terhadap minat bertransaksi menggunakan E-Banking pada UKM.

Dede dkk (2013) dalam penelitiannya menyatakan bahwa salah satu faktor penting yang mempengaruhi adopsi internet banking adalah kenyamanan, hemat waktu dan mudah digunakan dibandingkan dengan layanan perbankan konvensional.

\subsubsection{Automatic Teller Machine}

Di Indonesia juga dikenal ATM Bersama, yaitu jaringan antar bank yang menghubungkan jaringan ATM pada beberapa bank yang beroperasi di Indonesia. ATM Bersama menyediakan berbagai fasilitas antar bank, termasuk informasi saldo, penarikan tunai, dan real timeonline transfer ke account lain anggota jaringan bersama.

Pada dunia perbankan, perkembangan teknologi informasi membuat para perusahaan mengubah strategi bisnis dengan menempatkan teknologi sebagai unsur utama dalam proses inovasi produk dan jasa (Ansori, 2018). Seperti halnya pelayanan electronic transaction (ebanking) melalui ATM, phone banking dan Internet Banking misalnya, merupakan bentuk-bentuk baru dari pelayanan bank yang mengubah pelayanan transaksi manual menjadi pelayanan transaksi yang berdasarkan teknologi.

Saat ini berbagai transaksi perbankan telah menggunakan teknologi informasi sehingga kegiatankegiatan yang dulu harus dilakukan melalui antrian yang cukup lama di counter bank kini dapat diwakili oleh mesin, yaitu Automatic Teller Machine (ATM). ATM adalah alat kasir otomatis tanpa orang, yang ditempatkan didalam atau diluar pekarangan bank, yang sanggup untuk mengeluarkan uang tunai dan menangani berbagai transaksi perbankan yang rutin.

\subsection{Metode Kualitatif}

Sugiyono (2017) menyatakan bahwa metode penelitian kualitatif memiliki beberapa makna yang didalamnya terkait penelitian naturalistik karena pengaplikasiannya secara alamiah (natural setting); makna lainnya adalah metode etnografi, karena awalnya metode ini seringkali digunakan untuk penelitian anthropology budaya. Pemilihan metode kuanlitatif dalam penelitian disesuaikan dengan alur pelaksaan penelitian ini. Adapun alur pelaksanaan penelitian dapat dilihat pada gambar 1 di bawah ini.

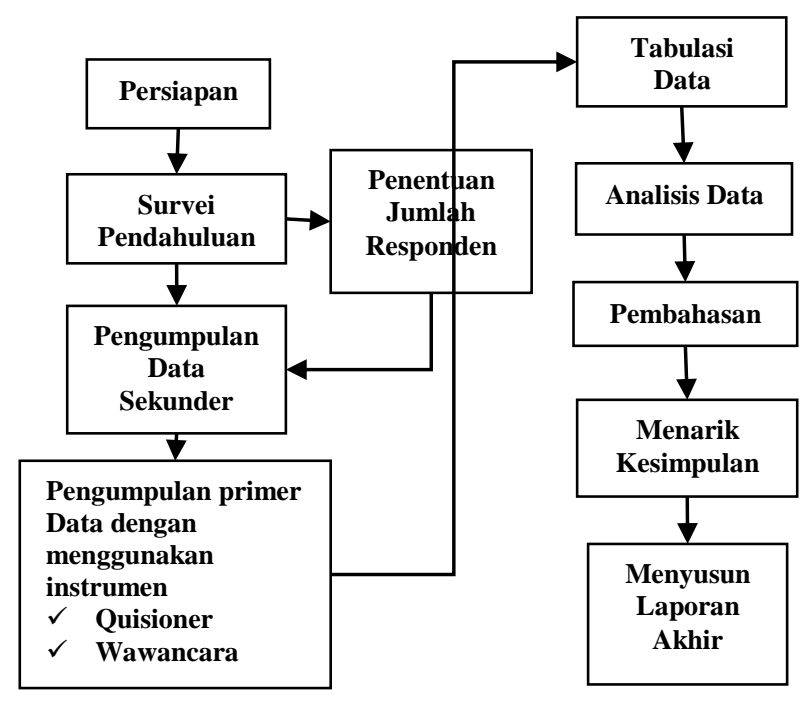

Gambar 1. Diagram alur pelaksanaan penelitian

Penelitian ini dimulai dengan melakukan persiapan penelitian yang kemudian dilanjutkan dengan survei pendahuluan untuk menentukan jumlah respon yang akan menjadi objek penelitian, dapat dilihat pada gambar 1. Langkah selanjutnya adalah pengumpulan data primer dengan menggunakan instrumen yakni kuesioner dan lembar wawancara. Dari data yang dihasilkan maka dilakukan tabulasi data sebagai bahan analisis data. Hasil analisis data tersebut akan dituangkan dalam pembahasan untuk selanjutnya ditarik kesimpulan.

\section{PEMBAHASAN}

Pada pembahasan penelitian ini fokus pada hubungan beberapa variabel. Hal yang dipaparkan adalah pemanfaatan internet banking dan automatic teller machine terhadap peningkatan usaha pelaku UMKM yang berada di pasar induk Wonomulyo. Pemanfaatan masing-masing variabel penelitian terhadap peningkatan usaha dapat dilihat pada penjelasan di bawah ini.

\subsection{Pemanfaatan Internet Banking terhadap Peningkatan Usaha Oleh Pelaku UMKM Pasar Induk Wonomulyo}

Hasil analisis deskriptif pada variabel pemanfaatan internet banking terhadap peningkatan UMKM diperoleh nilai minimum sebesar 20; nilai maksimum sebesar 51; nilai mean sebesar 27,35; dan standar deviasi sebesar 9,74 . Untuk menyusun distribusi frekuensi variabel pemanfaatan internet banking dapat dilihat pada tabel 1 . 
Tabel 1. Distribusi Frekuensi Minat Bertransaksi Menggunakan Internet Banking

\begin{tabular}{|c|c|c|}
\hline No. & Kelas Interval & Frekuensi \\
\hline 1. & $20,0-24,5$ & 31 \\
\hline 2. & $24,6-29,1$ & 13 \\
\hline 3. & $29,2-33,7$ & 0 \\
\hline 4. & $33,8-38,3$ & 0 \\
\hline 5. & $38,4-42,9$ & 0 \\
\hline 6. & $43,0-47,5$ & 1 \\
\hline 7. & $47,6-52,1$ & 7 \\
\hline \multicolumn{2}{|r|}{ Jumlah } & 52 \\
\hline
\end{tabular}

Sumber: Data Primer yang telah diolah, 2019

Berdasarkan tabel 1, maka dapat disimpulkan bahwa sebagian besar pelaku UMKM di pasar induk Wonomulyo melakukan transaksi jual beli secara tradisional (kurang maksimal memanfaatkan teknologi dan fasilitas perbankan berupa internet banking) dapat dilihat pada tabel 1. di atas, kelas interval terendah 20,0 24,5 sebanyak 31 pelaku UMKM. Pada Kelas interval tertinggi 47,6 - 52,1 memanfaatkan teknologi dan fasilitas perbankan berupa internet banking dalam melakukan jual beli sebanyak 7 pelaku UMKM. Pemanfaatan internet banking oleh pelaku UMKM di pasar induk Wonomulyo dapat dilihat dalam bentuk histogram pada gambar 2. histogram distribusi frekuensi Minat Bertransaksi Menggunakan Internet Banking.

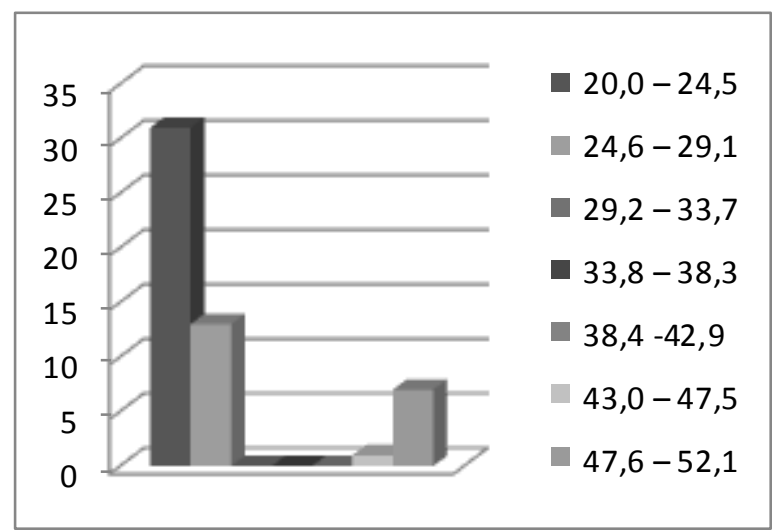

Gambar 2. Histogram Distribusi Frekuensi Minat Bertransaksi Menggunakan Internet Banking

Berdasarkan data tabel 1. dan Gambar 2. histogram frekuensi pemanfaatan internet banking menunjukkan bahwa nilai frekuensi terbesar adalah 31 , yaitu terletak pada interval $20,0-24,5$. Nilai frekuensi terendah terletak pada interval 29,2 - 33,7; 33,8 - 38,3 dan 38,4 42,9 sebanyak 0 responden. Kecenderungan frekuensi variabel ditentukan dengan menghitung Mean Ideal (Mi) 45 dan Standar Deviasi ideal sebesar 10. Hal ini menggambarkan bahwa sebagian besar pelaku UMKM di pasar induk Wonomulyo melakukan transaksi jual beli secara tradisional (kurang maksimal memanfaatkan teknologi dan fasilitas perbankan berupa internet banking), dimana penjual berkumpul di suatu tempat dan pembeli datang untuk melakukan transaksi jual beli.
Pengkategorian kecenderungan frekuensi data variabel pemanfaatan Internet Banking pada Pelaku Usaha di Pasar Induk Wonomulyo dihitung berdasarkan Mean ideal dan Standar Deviasi ideal dapat dilihat pada Tabel 2 kecenderungan frekuensi data variabel.

Tabel 2. Kategori Kecenderungan Frekuensi Variabel Pemanfaatan Internet Banking

\begin{tabular}{|c|c|c|c|c|}
\hline No. & Interval & Frekuensi & Persentase & Kategori \\
\hline 1. & $>55$ & - & - & Tinggi \\
\hline 2. & 35 s/d 55 & 8 & $15,4 \%$ & Sedang \\
\hline 3. & $<35$ & 44 & $84,6 \%$ & Rendah \\
\hline \multicolumn{2}{|c|}{ Total } & $\mathbf{5 2}$ & $\mathbf{1 0 0 \%}$ & \\
\hline
\end{tabular}

Tabel 2 menunjukkan bahwa variabel pemanfaatan Internet Banking pada Pelaku Usaha di Pasar Induk Wonomulyo kategori sedang adalah sebesar 8 responden $(15,4 \%)$ sedangkan kategori rendah sebanyak 44 responden $(84,6 \%)$. Berdasarkan tabel 2 kategori kecenderungan variabel di atas, ditampilkan dalam diagram Pie pada gambar 3.

\section{Internet Banking}

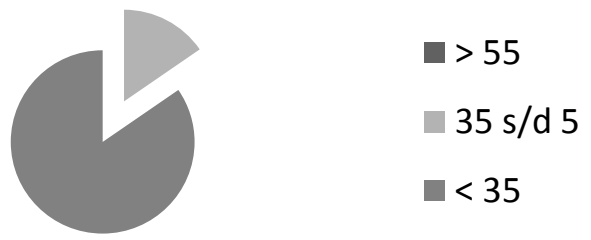

\section{Gambar 3. Pie-Chart Variabel Minat Bertransaksi Menggunakan Internet Banking}

Hasil penelitian menunjukan bahwa internet banking tidak memiliki pengaruh signifikan terhadap peningkatan usaha pelaku UMKM di Pasar Induk Wonomulyo. Hasil pengujian hipotesis pertama jelas kurang tersentuh revolusi industri 4.0 dimana pada revolusi industri 4.0 memicu adanya pemanfaatan smartphone dalam memudahkan dan meningkatkan hasil dari kegiatan usaha. Dengan adanya smartphone yang dimiliki oleh semua lapisan masyarakat akan memudahkan pelaku UMKM menggunakan internet banking dalam proses penjualan secara online maupun tidak. Internet banking yang merupakan fasilitas yang diberikan oleh pihak perbankan kepada nasabah/pelaku usaha bertujuan untuk meningkatkan usaha pelaku UMKM sehingga perputaran uang tinggi di wilayah tersebut. Hal ini tidak hanya menguntungkan pelaku UMKM saja, tetapi akan berdampak positif kepada peningkatan perbankan dan peningkatan pendapatan daerah terkait.

Hipotesis awal pada penelitian ini ditolak ketika telah dilakukan penyebaran kuesioner dan pengolahan data atas informasi/data yang diperoleh. Hasil penelitian ini menyatakan bahwa internet banking tidak memiliki pengaruh signifikan terhadap peningkatan usaha pelaku UMKM di Pasar Induk Wonomulyo. Kondisi ini terjadi 
karena sebagian besar dari pelaku UMKM yang menjadi responden masih melakukan transaksi jual beli secara tradisional. Transaksi yang bersifat tradisional ini dimana pembeli secara langsung mengunjungi pasar induk untuk pemenuhan kebutuhan, baik berupa membeli pakaian, bahan campuran, pecah belah dan lainnya.

Transaksi yang bersifat tradisional yang masih dilakukan di Pasar Induk Wonomulyo, bukan karena perkembangan dan pemanfaatan alat elektronik tidak memadai, namun hal ini terjadi karena teknologi berupa handphone pintar atau smartphone yang dimiliki oleh pelaku usaha hanya digunakan untuk memenuhi kebutuhan hiburan ketika dalam kondisi tidak ada pelanggan yang mengunjungi toko. Jadi, smartphone dimanfaatkan untuk, menghubungi bos, relasi kerja, kelurga atau teman; menonton video; mendengar musik; bermain di dunia maya dengan memanfaatkan sosial media; tidak dimanfaatkan dalam pemasaran produk yang mereka perdagangkan.

\subsection{Pemanfaatan Automatic Teller Machine (ATM) Terkait Peningkatan Usaha Oleh Pelaku UMKM Pasar Induk Wonomulyo}

Hasil analisis deskriptif pada variabel pemanfaatan automatic teller machine terhadap peningkatan UMKM diperoleh nilai minimum sebesar 49; nilai maksimum sebesar 56; nilai mean sebesar 52,56; dan standar deviasi sebesar 1,73. Distribusi frekuensi variabel pemanfaatan automatic teller machine dapat dilihat pada tabel 3 di bawah ini.

Tabel 3. Distribusi Frekuensi Minat Bertransaksi Menggunakan automatic teller machine

\begin{tabular}{|c|c|c|}
\hline No. & Kelas Interval & Frekuensi \\
\hline 1. & $49,0-50,0$ & 5 \\
2. & $50,1-51,1$ & 7 \\
3. & $51,2-52,2$ & 17 \\
4. & $52,3-53,3$ & 3 \\
5. & $53,4-54,4$ & 15 \\
6. & $54,5-55,5$ & 3 \\
7. & $55,6-56,6$ & 2 \\
\hline \multicolumn{2}{|c|}{ Jumlah } & $\mathbf{5 2}$ \\
\hline
\end{tabular}

Sumber: Data Primer yang telah diolah, 2019

Berdasarkan tabel 3 di atas, maka dapat dilihat dengan jelas bahwa minat bertransaksi menggunakan automatic teller machine beragam dan ada yang menggunakan ATM dengan intensitas yang tinggi, sedang dan rendah. Histogram distribusi frekuensi Minat Bertransaksi Menggunakan automatic teller machine dapat dilihat pada gambar 4 .

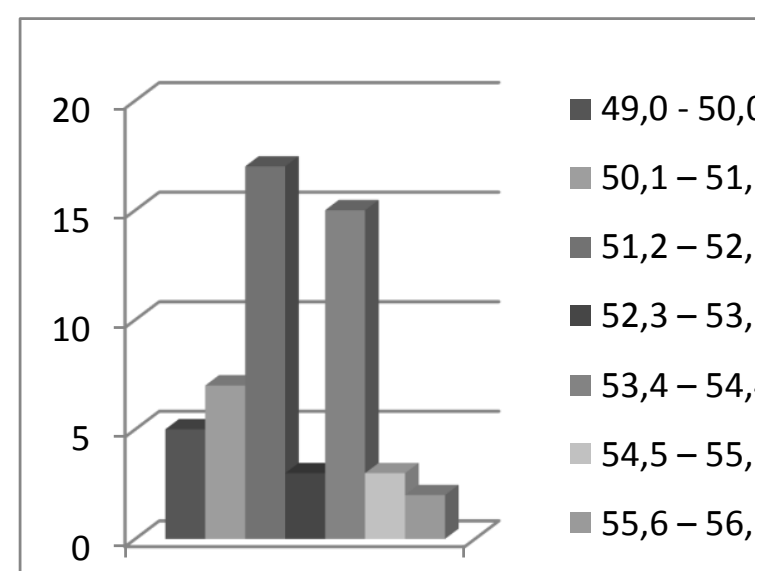

Gambar 4. Histogram Distribusi Frekuensi Minat Bertransaksi Menggunakan automatic teller machine

Berdasarkan data tabel 3 dan gambar 4 histogram frekuensi di atas menunjukkan bahwa nilai frekuensi terbesar adalah 15, yaitu terletak pada interval 53,4 54,4 . Nilai frekuensi terendah terletak pada interval 55,6 - 56,6 sebanyak 2 responden. Kecenderungan frekuensi variabel ditentukan dengan menghitung Mean Ideal (Mi) 42 dan Standar Deviasi ideal sebesar 9.

Pengkategorian kecenderungan frekuensi data penggunaan automatic teller machine pada Pelaku Usaha di Pasar Induk Wonomulyo dihitung berdasarkan Mean ideal dan Standar Deviasi ideal dapat dilihat pada Lampiran. Kecenderungan frekuensi data variabel tersebut dapat dilihat pada tabel 4.

Tabel 4. Kategori Kecenderungan Frekuensi Variabel penggunaan automatic teller machine

\begin{tabular}{|c|c|c|c|c|}
\hline No. & Interval & Frekuensi & Persentase & Kategor \\
\hline 1. & $>51$ & 40 & $76,92 \%$ & Tinggi \\
\hline 2. & $33 \mathrm{~s} / \mathrm{d} 51$ & 12 & $23,08 \%$ & Sedang \\
\hline 3. & $<33$ & - & - & Rendah \\
\hline & Total & 52 & $100 \%$ & \\
\hline
\end{tabular}

Tabel 4 di atas menunjukkan bahwa variabel Minat Bertransaksi Menggunakan automatic teller machine pada Pelaku Usaha di Pasar Induk Pasar Induk Wonomulyo kategori tinggi adalah sebesar 40 responden $(76,92 \%)$ sedangkan kategori sedang sebanyak 12 responden $(23,08 \%)$. Berdasarkan kategori kecenderungan variabel di atas, dapat pula ditampilkan dalam bentuk diagram Pie pada gambar 5 di bawah ini. 


\section{Automatic Teller Machine}

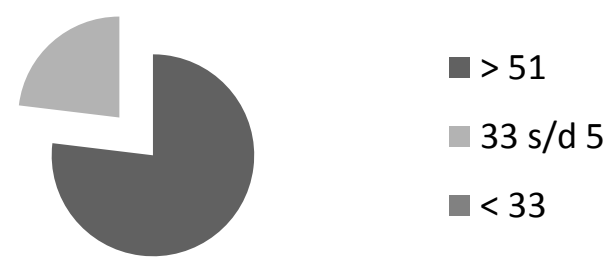

\section{Gambar 5. Pie-Chart Variabel Minat Bertransaksi Menggunakan automatic teller machine}

Hipotesis kedua ini pun ditolak karena hasil penelitian menunjukkan bahwa pemanfaatan automatic teller machine (ATM) tidak berpengaruh signifikan terhadap peningkatan usaha pelaku UMKM di Pasar Induk Wonomulyo. Dengan demikian, dapat dikatakan bahwa peningkatan usaha yang terjadi pada usaha pelaku UMKM di Pasar Induk Wonomulyo tidak dipengaruhi oleh tingginya tingkat kemudahan dan penggunaan automatic teller machine.

Pemanfaatan ATM dikalangan pelaku UMKM di Pasar Induk Wonomulyo sebatas melakukan pembayaran pada pemasok barang yang menjadi distributor atau produsen yang menyediakan barang untuk diperdangkan kembali. Karena kurang maksimal dalam pemanfaatan automatic teller machine (ATM) sehingga penggunaan automatic teller machine tidak berpengaruh signifikan terhadap peningkatan usaha pelaku UMKM di Pasar Induk Wonomulyo. Kesimpulan yang diperoleh adalah layanan automatic teller machine memberikan manfaat kepada pelaku usaha yang ada di Pasar Induk Wonomulyo dalam menunjang aktivitas penyediaan barang yang terkait, secara tidak langsung pada kelancaran dan peningkatan usaha. Dengan adanya kondisi demikian, mereka berminat untuk menggunakan layanan automatic teller machine (ATM) dengan berbagai kemudahannya walaupun harus mengunjungi ATM terdekat untuk melakukan transfer, cek saldo rekening dan membayar tagihan.

Automatic teller machine (ATM) dimanfaatkan oleh pelaku usaha di Pasar Induk Wonomulyo namun intensitas pemanfaatannya untuk kegiatan usaha masih rendah. Rendahnya intensitas pemanfaatan automatic teller machine (ATM) dikarenakan pada saat ingin memasok barang, kadang kala sebagian besar pelaku usaha di Pasar Induk Wonomulyo melakukan perjalanan menuju lokasi penyedia barang (konveksi Jakarta, Bandung, Surabaya dan lainnya) dan langsung membayar secara tunai

\section{KESIMPULAN}

Hasil penelitian ini menunjukkan bahwa pemanfaatan internet banking terbukti berpengaruh negatif terhadap peningkatan usaha pada pelaku UMKM di Pasar Induk Wonomulyo. Hal ini berarti minat bertransaksi menggunakan internet banking pada pelaku UMKM
Pasar Induk Wonomulyo dipengaruhi oleh kebermanfaatan selebihnya dipengaruhi faktor lain diluar penelitian ini.

Hasil pemanfaatan automatic teller machine terbukti berpengaruh negatif terhadap peningkatan usaha pada pelaku usaha di Pasar Induk Wonomulyo. Hal ini berarti pemanfaatan automatic teller machine pada pelaku usaha di Pasar Induk Wonomulyo mempengaruhi peningkatan usaha walau tidak signifikan, selebihnya dipengaruhi faktor lain diluar penelitian ini.

Sebagian besar dari pelaku UMKM yang berada dalam lingkup Pasar Induk Wonomulyo menggunakan jasa anak-anak atau remaja yang tidak bersekolah untuk menjaga stand atau toko, sehingga kreativitas dan inovasi dalam memasarkan dagangan mereka relatif rendah karena tidak merasa memiliki usaha tersebut. Hal lain yang menjadi sangat disayangkan karena sebagian besar pelaku UMKM dan penjaga toko memiliki smartphone tetapi tidak dimanfaatkan secara maksimal dalam peningkatan usaha, sehingga revolusi industri 4.0 yang memanfaatkan teknologi dalam pengembangan masih kurang dipahami oleh pelaku UMKM di Pasar Induk Wonomulyo.

\section{SARAN}

Penelitian selanjutnya sebaiknya menggunakan penelitian dengan ruang lingkup yang lebih luas. Penelitian selanjutnya dapat menambahkan jumlah responden yang digunakan dalam penelitian sehingga hasil yang diperoleh dapat lebih mencerminkan keadaan yang sebenarnya.

Perlu dilakukan penelitian lebih lanjut terkait dengan faktor-faktor lain yang mempengaruhi peningkatan usaha Pelaku UMKM untuk menggunakan layanan internet banking dan automatic teller machine dalam menyelesaikan transaksi bisnisnya, seperti kepercayaan, reputasi dan kualitas informasi. Dengan demikian, mampu memicu pengembangan usaha dan menumbuhkan kepercayaan konsumen sehingga penjualan mengalami peningkatan. Peningkatan penjualan dapat meningkatkan pertumbuhan ekonomi pada wilayah terkait. Serta memberikan peluang kepada pelaku UMKM melakukan penjualan hingga ke luar kota atau pulau dengan pemanfaatan teknologi secara maksimal.

\section{DAFTAR PUSTAKA}

Andriyani, Ory; Cangara, Hafied ; Sadjad, Rhiza S. 2014. Penggunaan Teknologi Informasi Online Dalam Kecepatan Pelayanan Dan Pengamanan Pada Bank Bca Makassar (Sebuah Studi Komunikasi Organisasi). Jurnal Komunikasi KAREBA Vol. 3, No. 1.

Ansori, Aan. 2018. Sistem Informasi Perbankan Syari'ah. Jurnal Banque Syar'i Vol. 4 No. 1.

Dede D.N, Tyas S.A dan Karina O. 2013. Analisis Faktor-Faktor yang Mempengaruhi Nasabah 
Menggunakan Layanan Internet Banking Mandiri. Manajemen Bisnis Telekomunikasi dan Informatika, Universitas Telkom. Jurnal Manajemen, Vol.13, No.1.

Diana G. 2017. Analisis Pengaruh Automatic Teller Machine dan Short Message Service Banking terhadap Kepuasan Nasabah. Jurnal Elektronik Sistem Informasi dan Komputer Vol.3 No.1.

Harlan, Dwimastia. 2014. Pengaruh Kemudahan Penggunaan, Kepercayaan Dan Risiko Persepsian Terhadap Minat Bertransaksi Menggunakan EBanking Pada Umkm Di Kota Yogyakarta. Skripsi Fakultas Ekonomi Universitas Negeri Yogyakarta. http://eprints.uny.ac.id/16809/1/Full\%20Skripsi.pdf
Kasmir. 2014. Bank dan Lembaga Keuangan Lainnya. Jakarta: Rajawali Pers.

Kotler dan Keller. 2010. Manajemen Pemasaran. Jakarta: Erlangga.

Robert K.D. 2013. Banking Innovation in Ghana: Insight of Students' Adoption and Diffusion. Journal of Internet Banking and Commerce, Vol.18, No.3.

Suci, Yuli Rahmini. 2017. Perkembangan Umkm (Usaha Mikro Kecil Dan Menengah) Di Indonesia. Jurnal Ilmiah Cano Ekonomos Vol. 6 No. 1.

Sugiyono. 2017. Metode penelitian bisnis Pendekatan Kuantitatif, Kualitatif, Kombinasi, dan $R \& D$. Bandung: Alfabeta. 